

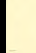
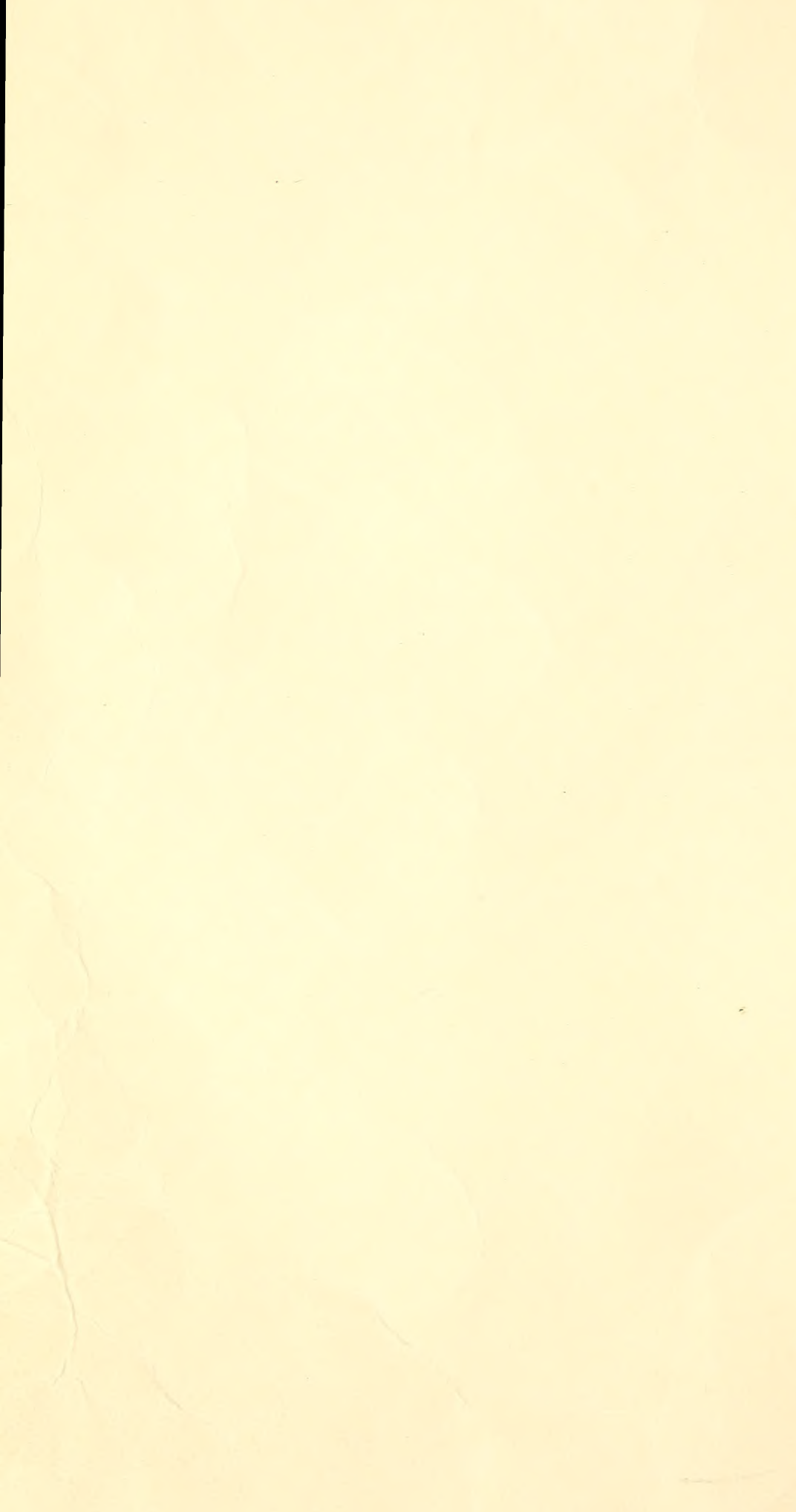
Historic, archived document

Do not assume content reflects current scientific knowledge, policies, or practices. 



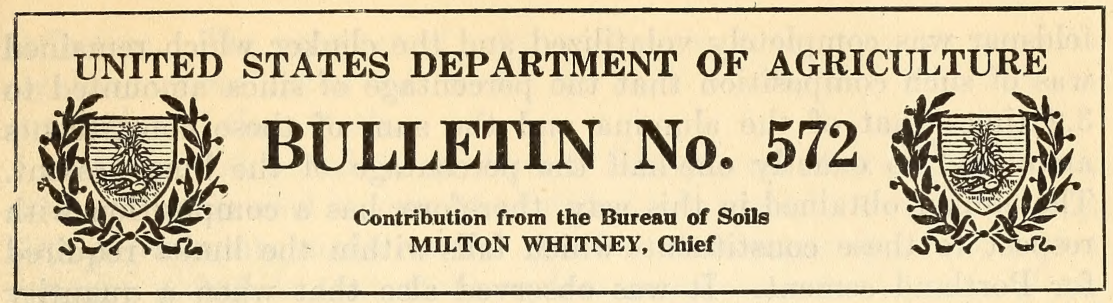

Washington, D. C.

PROFESSIONAL PAPER

October 5, 1917

\title{
THE RECOVERY OF POTASH AS A BY-PRODUCT IN THE CEMENT INDUSTRY.
}

\author{
By William H. Ross, Albert R. Merz, and C. R. Wagner, \\ Scientists in Soil Laboratory Investigations.
}

\section{CONTENTS.}

Introduction

Potash in raw materials and loss through volatilization in cement manufacture........

Percentage of volatilization of potash in cement plants..........................

Reliability of the results obtained...........
Page.

Estimated percentage of potash in the flue dust from different plants............... 15

3 Ratio of potash to soda in cement dust..... 17 Potash-producing plants in the United States. $\quad 18$ Acknowledgment........................ 22

14 Summary ........................... 22

\section{INTRODUCTION.}

The present work is a continuation of an investigation that has been in progress in this laboratory for several years on the practicability of recovering potash from silicate rocks. Early in the investigation the conclusion was reached that owing to the small percentage of potash in commercial grades of any insoluble potash silicate, no process for recovering potash from such material can offer much promise of profitable application unless at the same time some product of value is recovered in addition to the potash. This principle now seems to be more or less generally recognized, and in the numerous patents that have appeared during the last two or three years on the subject of decomposing feldspar and other potash silicates specifications are given in most cases for the recovery, in addition to potash, of one or more of such various products as compounds of aluminum and of silicon, cement, raw material for the manufacture of glass or pottery, structural material, and pigment.

In a publication ${ }^{1}$ prepared about five years ago, it was shown that when 1 part of feldspar and 3 parts of calcium carbonate were ignited about an hour at a temperature of $1,300-1,400^{\circ}$, the potash in the

1 Ross, William H., Circular No. 71, Bureau of Soils; Eighth Intern. Congress of Applied Chemistry, 15, 217 (1912).

$103837^{\circ}-17-$ Bull. $572-1$ 
feldspar was completely volatilized and the clinker which remained was of such composition that the percentage of silica amounted to 3.2 times that of the alumina and the sum of these constituents amounted to exactly one-half the percentage of the lime present. The clinker obtained in this way, therefore, has a composition with respect to these constituents which falls within the limits required for Portland cement. It was observed also that when a quantity of calcium chloride equivalent to the alkalies in the feldspar was substituted for a part of the lime, volatilization took place in about half the time required when the ignition was made with lime alone: and that with the same mixture, on extending the time of ignition, almost complete decomposition of the feldspar could be effected at a temperature as low as $1,050^{\circ}$. Substitution of sodium chloride for calcium chloride gave approximately the same results.

In a later publication ${ }^{1}$ it was shown that'when feldspar and lime in the proper proportion to make cement are digested with water at a steam pressure of 10 to 15 atmospheres, about 90 per cent of the potash in the feldspar passes into solution in the form of the hydroxide and the residue simply requires ignition for the manufacture of Portland-cement clinker. When the proportion of lime taken is reduced much below the limit stated, only partial decomposition of the feldspar results even at increased pressures, but by adding to such a mixture a quantity of a soluble calcium salt equivalent to the alkalies in the feldspar the amount of potash recovered may then be increased considerably.

The conclusion was drawn from these experiments that potash could be set free from feldspar by substituting the latter for clay in the manufacture of cement; that the potash would be volatilized to a greater or less extent and could be recovered in the flue dust; and that it should be possible to obtain raw materials of the proper composition to yield Portland-cement clinker on ignition.

In a series of experiments recently described by Anderson and Nestell, ${ }^{2}$ cement mixtures from 10 different plants in this country and Japan were ignited in a way similar to that used in the ignition of the feldspar-lime mixtures. In every respect the results corresponded to those which were obtained in this laboratory by the ignition of feldspar with lime. Thus it was found that with different cement mixtures volatilization of the potash began at about $1,100^{\circ}$; at $1,200^{\circ}$ the percentage of potash volatilized in a given time was different for the different mixtures, but when the temperature was increased to $1,300^{\circ}$, and maintained for 1 hour, almost complete volatilization resulted in every case. When heating an hour at $1,200^{\circ}$ the addition of 5 per cent of sodium chloride to the raw material gave an increase in volatilization of the potash from 19 per cent to 66 per cent, while the use of calcium chloride was reported to be even more 
effective. The presence of sulphur dioxide in the furnace when the ignitions were made was found to have a retarding effect on the evolution of the potash.

Since potash occurs in the form of feldspar or other silicates in the raw materials used in cement manufacture, it might be inferred from the experiments made on the ignition of feldspar mixtures and of cement materials that more or less complete volatilization of the potash would take place in the burning of cement.

It happens, however, that the clinkering zone of a rotary kiln constitutes only a comparatively short portion of its length, and while the time taken for the charge to pass through the kiln may vary from about $1 \frac{1}{2}$ to $2 \frac{1}{2}$ hours, depending on the length of the kiln, the time that the charge is subjected to a clinkering temperature does not exceed one-half hour. The length of a rotary kiln must also act disadvantageously on the escape of the potash. That some potash is volatilized in cement burning has long been known, and in the case of one plant a quantitative study of the amount lost in this way has been made by $R$. K. Meade ${ }^{1}$ from analyses of the raw material fed into the kiln, the resulting clinker, and the coal used for burning. The results of three separate tests showed that the potash volatilized ranged from 46 to 52 per cent.

\section{POTASH IN RAW MATERIALS AND LOSS THROUGH VOLATILIZATION IN CEMENT MANUFACTURE.}

With a view to securing more extended information in this direction, an investigation was undertaken about five years ago to ascertain the percentage of potash occurring in the raw materials used in the different cement plants of this country and also the percentage of the total potash that is volatilized in each case. Representative samples of raw mix and ground clinker were collected from the different cement plants in the United States and in Canada, with a view to analyzing each sample for potash. With the data thus obtained, and knowing the ratio between the raw mix and the cement produced, and the output of the latter, it was thought possible to calculate for each plant the approximate quantity of potash that escapes daily from the kilns. After the work was partly completed it had to be abandoned for a time. A few months ago the problem was taken up again and entirely new samples were collected. The work now has been completed, with the results given in Table I.

This table shows that the potash occurring in the raw mix used by the different cement plants in this country varies from 0.20 to 1.16 per cent. The raw materials used in the mills of the Universal Portland Cement Co. consisting of blast-furnace slag and a high-grade limestone contain considerably less potash than the average for the other cement plants of the country. 


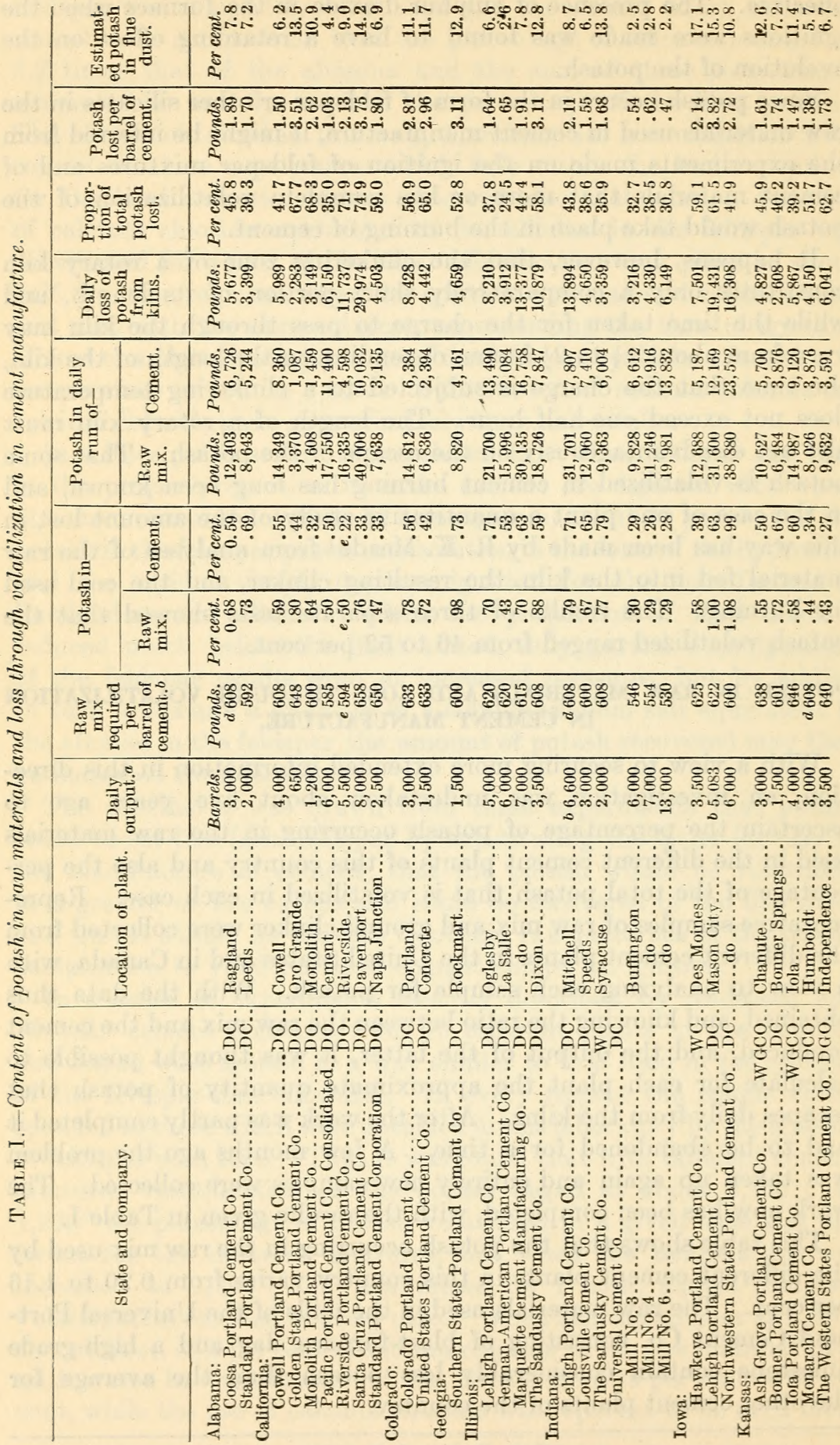




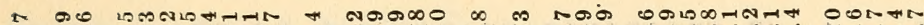

के

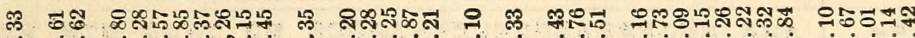

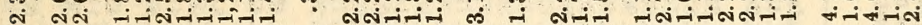

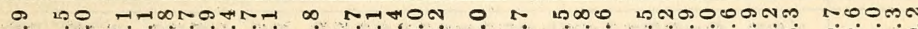

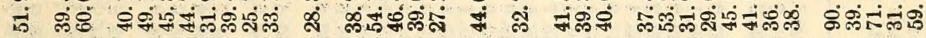

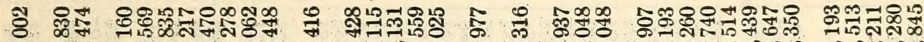

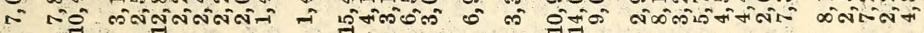

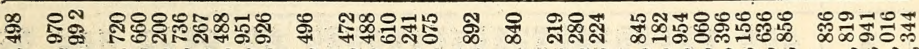

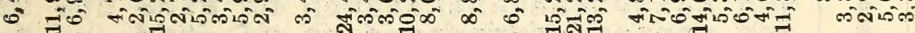

윰 \&ళ \&

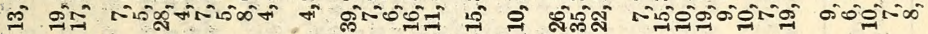

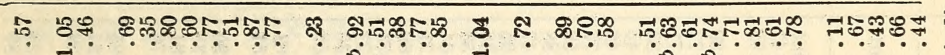

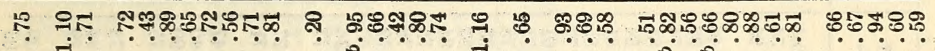

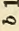

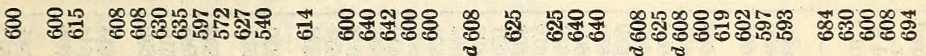

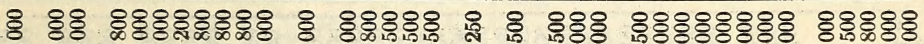

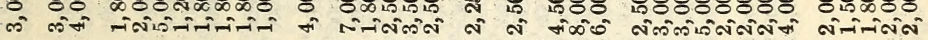
o

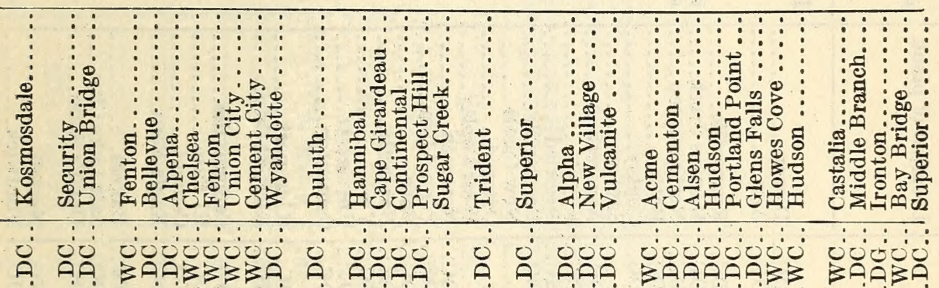

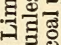




\begin{tabular}{|c|c|c|c|c|c|c|c|}
\hline \multicolumn{2}{|c|}{ 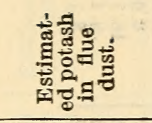 } & 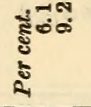 & 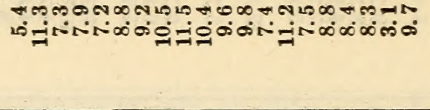 & $\infty \dot{\theta}$ & 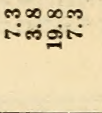 & ம்่ง் & $\ddot{=}$ \\
\hline \multicolumn{2}{|c|}{ 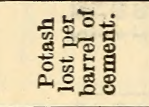 } & 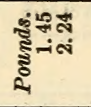 & 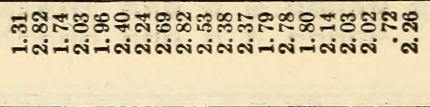 & 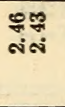 & 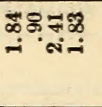 & 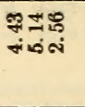 & శ్ర్ల \\
\hline \multicolumn{2}{|c|}{ 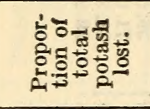 } & 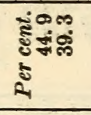 & 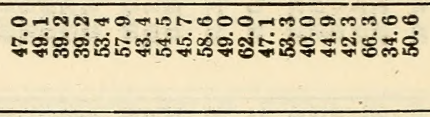 & क्ष & 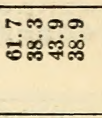 & 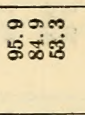 & 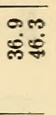 \\
\hline \multicolumn{2}{|c|}{ 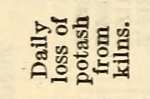 } & 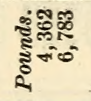 & 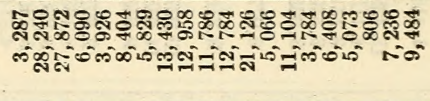 & $\begin{array}{l}\infty \\
\infty \\
\infty\end{array}$ & 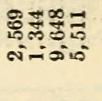 & 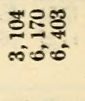 & 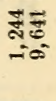 \\
\hline \multirow{2}{*}{ 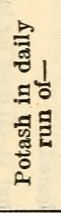 } & : & 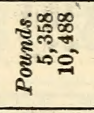 & 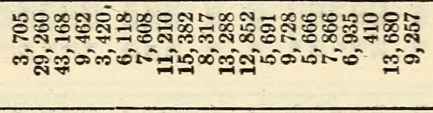 & $\begin{array}{l}\text { है: } \\
\text { î: } \\
\text { on }\end{array}$ & 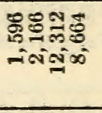 & 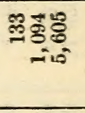 & 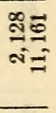 \\
\hline & 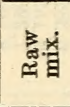 & 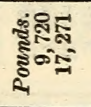 & 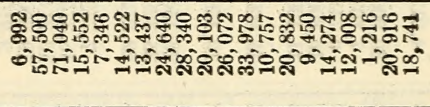 & 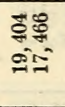 & 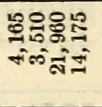 & 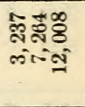 & 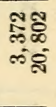 \\
\hline \multirow{2}{*}{ 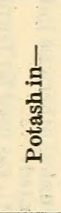 } & $\begin{array}{l}\dot{\tilde{\Xi}} \\
\stackrel{\Xi}{0} \\
\end{array}$ & 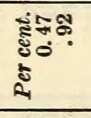 & 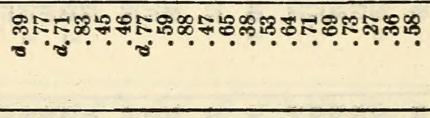 & ชุ. & 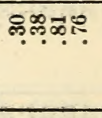 & อำำ & $\stackrel{\infty}{\infty \infty \infty}$ \\
\hline & 崫宵 & 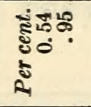 & 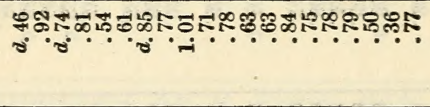 & 듀. & $?$ & R & क্ণে? \\
\hline \multicolumn{2}{|c|}{ 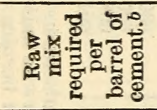 } & 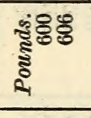 & 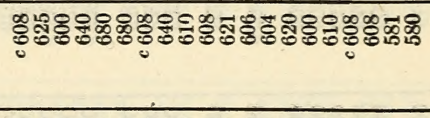 & ్ํㅇำ & 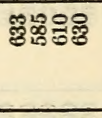 & & $\vec{x}$ \\
\hline \multicolumn{2}{|c|}{ 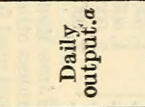 } & 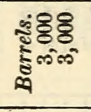 & 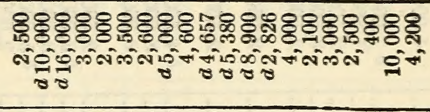 & ஜ్రిᄋ్ & 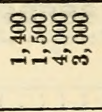 & 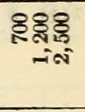 & 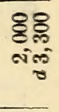 \\
\hline \multicolumn{2}{|c|}{ 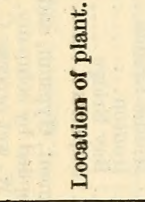 } & 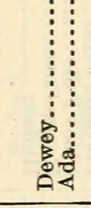 & 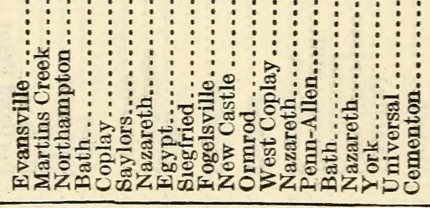 & 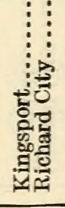 & 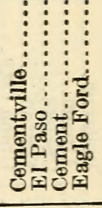 & 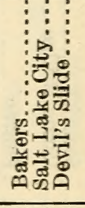 & 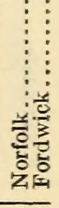 \\
\hline \multicolumn{2}{|c|}{ 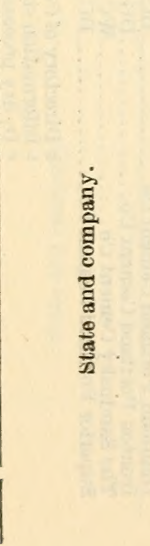 } & 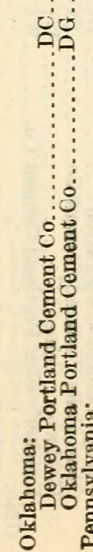 & $\begin{array}{l} \\
\vdots\end{array}$ & 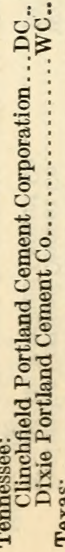 & 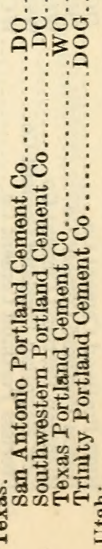 & 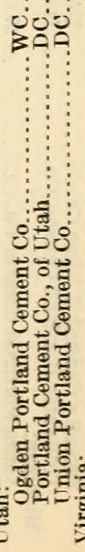 & 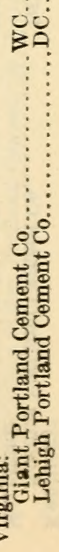 \\
\hline
\end{tabular}




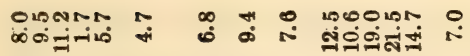


In a communication received from the manager of one of the large cement plants in the Lehigh Valley district the statement was made that the raw cement material used in this district contains less than 0.3 per cent. The samples analyzed in these experiments, however, indicate that in no case does the raw mix used in the plants of this district run as low as 0.3 per cent, but that some of these plants make use of cement material almost as rich in potash as may be found in any cement plant in the country. In general it may be stated, however, that high potash-bearing raw material is not characteristic of any particular part of the country.

The values given in Table I for the potash contained in the daily production of cement were obtained by multiplying the output in barrels by the weight of one barrel (380 pounds) and by the percentage of potash in the cement as found by analysis. To obtain the corresponding values for the potash in the daily run of raw mix, the output of cement expressed in barrels was multiplied by the weight of raw mix required per barrel of cement and then by the percentage of potash in the raw mix. The difference between the two values as thus determined represents the potash that escapes daily from the kilns. As shown in the table, this varies in different plants from 0.35 to 5.14 pounds of $\mathrm{K}_{2} \mathrm{O}$ per barrel of cement produced. The average for all the plants listed in the table when consideration is taken of the variation in output of cement of the different plants amounts to 1.93 pounds ${ }^{1}$ per barrel of cement.

Omitting the plants of the Universal Portland Cement Co., the corresponding average for the remainder of the 99 plants of this country from which samples were received amounts to 2.09 pounds. The average for the nine Canadian plants is 1.95 pounds. The total number of plants in this country from which samples were received is only four less than the total number which operated in $1915^{2}$ and nine less than the total number said to be in operation in 1916.

The average daily output of cement from the individual plants in many cases is considered confidential information. In Table I, therefore, it was necessary to give ralues for the output of the individual plants which represent capacities rather than actual production. The total annual production as obtained from these values is consequently much in excess of that which is known to have been produced in any one year. The values given for the potash lost per barrel of cement are, however, independent of the output. If, therefore, the average annual production of Portland cement in

\footnotetext{
1 In making this calculation no account was taken of the potash in the coal, which at most would not amount to more than a few tenths of a pound per barrel of cement. Any potash present, however, would tend to increase the value given for the amount of potash volatilized. Cf. R. K. Meade, Portland Cement, 2d ed., p. 179.

2 Burchard, E. F.. Cement in 1915. Mineral resources of the U. S., 1915, Part II, p. 195.
} 
this country be now taken in round numbers as $90,000,000$ barrels $^{1}$ and if the same average conditions be assumed to prevail in the few plants from which no samples were received as was found on an average for all other plants, then it may be estimated that the total potash $\left(\mathrm{K}_{2} \mathrm{O}\right)$ escaping from all the cement plants in this country as at present operated amounts to 86,850 tons annually.

The process at present most generally considered in connection with the recovery of the potash that escapes from cement kilns is electrical precipitation. The extent to which the dust may be recovered in this way is dependent, assuming proper installation, on the voltage used and the linear velocity with which the gases pass through the treater pipes. The volume of gases treated being constant, the degree of precipitation of the dust will be dependent on the extent of the installation. With present installations a recovery of approximately 99 per cent ${ }^{2}$ of the dust has been obtained. It happens, however, that the finest portion of the dust escaping from any cement plant contains relatively the highest percentage of potash, and a 99 per cent recovery of the dust represents a somewhat less efficient recovery of the potash.

In the plant of the Security Cement and Lime Co., where the Cottrell process of electrical precipitation has been installed, it is found that under normal working conditions, and with a daily output of 2,500 barrels, the dust collected in the kiln stacks amounts to 16,000 pounds and in the treaters 45,000 pounds every 24 hours. The former contains on an average 4.5 per cent potash, and the latter, as analyzed in this laboratory, 11.4 per cent, making a total of 5,850 pounds of potash recovered daily. As shown in Table I, the potash lost from the kilns during the same period amounts to 6,525 pounds. On this basis of calculation the potash recovery in this plant amounts to 90 per cent of the total. If this value be accepted as the efficiency of recovery of the potash in the most economic installations, then the total recoverable potash in the cement plants of this country under present working conditions amounts to 78,165 tons annually.

The potassium compounds occurring in cement dust may be divided into three groups, as follows: (1) Those which are readily soluble in water; (2) those which are slowly soluble; and (3) those which are insoluble.

The insoluble potash represents the combinations occurring in the original silicates of the raw mix carried over mechanically in the dust before being subjected to a sufficiently high temperature to bring about decomposition. The form of combination which is slowly soluble in water is supposed to be due to a recombination of the vola-

1 Burchard, E. F. Loc. cit.

2 Schmidt, W. A., Paper presented at the meeting of the American Institute of Mining Engineers, Globe, Ariz., Sept. 21, 1916.

$103837^{\circ}-17-$ Bull. $572-2$ 
tilized potash with the silicates in the dust. In some plants where coal is used for burning the extent to which the potash occurs in this "recombined" form may be considerable, while in certain other plants where oil is used for fuel this combination of the potash occurs in comparatively small amount. In Table II the percentages of the different forms of potash occurring in a dust from a plant which uses oil for fuel and also from one which uses coal are given:

TABLE II.-Percentages of the different combinations of potash in flue-dust samples from different sources.

\begin{tabular}{|c|c|c|}
\hline & \multicolumn{2}{|c|}{ Cement dust from- } \\
\hline Combination. & $\begin{array}{l}\text { Riverside } \\
\text { Portland } \\
\text { Cement } \\
\text { Co. }\end{array}$ & $\begin{array}{l}\text { Security } \\
\text { Cement } \\
\text { and Lime } \\
\text { Co. }\end{array}$ \\
\hline 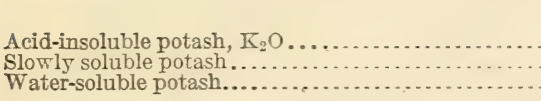 & $\begin{array}{r}\text { Per cent. } \\
0.2 \\
9.7 \\
9.8\end{array}$ & $\begin{array}{r}\text { Per cent. } \\
0.5 \\
4.1 \\
6.8\end{array}$ \\
\hline Total...... & 10.7 & 11.4 \\
\hline
\end{tabular}

The determinations of the soluble potash in thase samples were made by boiling 10 grams of the sample in 500 cubic centimeters of water for one-half hour as directed in the Methods of the Association of Official Agricultural Chemists. The insoluble potash was assumed to be that portion of the total potash which remained insoluble after boiling in a 5 per cent solution of hydrochloric acid. The difference between the total potash and the sum of the soluble and insoluble portions was then taken as the proportion of the potash which is slowly soluble in water.

In a previous publication it was shown, as already stated, that the greater part of the potash in feldspar may be made to pass into solution by digesting with lime under a steam pressure of 10 to 15 atmospheres. In cement dust as it escapes from the kilns the slowly soluble and the insoluble potash already are associated with a considerable percentage of free lime and consequently it was thought that the greater part of these consticuents might be recorered in soluble form by digesting the dust with steam alone under pressure. This has been found to be the case, and with the Security cement dust it has been found possible to recover in this way in soluble form and with little increase in pressure upward of 95 per cent of the total potash present. If it be assumed, therefore, that it would be practicable to recorer, or render available, say, 95 per cent ${ }^{1}$ of the potash in the recorerable dust of cement plants, then the recorerable and arailable potash escaping from the cement plants of this country amounts

1 In the case of coal-fired plants it may not be possible, with present commerciul apparatus, to render s)luble as much as 95 per cent of the collected potash, but there is no doubt that as details of commerc.sl apparatus are periected this value will represent a fair a verage for the different plants of the country. 
approximately to 75,000 tons annually. If, however, the dust from all plants losing less than 1 pound of potash per barrel of cement be considered as too low grade for use as a source of fertilizer material and the figures from such plants be omitted in the calculations, then the value for the available recoverable potash in the cement industry of this country as normally operated becomes 71,000 tons annually.

\section{PERCENTAGE OF VOLATILIZATION OF POTASH IN CEMENT PLANTS.}

As shown in Table $I$, the proportion of the total potash $\left(\mathrm{K}_{2} \mathrm{O}\right)$ that is volatilized varies in different plants from 24.5 to 95.9 per cent. The lowest values were obtained for plants widely separated from one another. In the Hudson River district the percentage volatilization varies from about 30 per cent to 45 per cent, and in the Lehigh Valley district from about 40 per cent to 60 per cent. In plants situated in the northern Central States considerable variation was noted. The highest values were found for plants located in southern California, and in Colorado and Utah.

It may be pointed out that as much variation occurs in the percentage of potash volatilized trom plants using oil as from those using coal. It is also to be noted that the average percentage volatilization (46 per cent) in plants using the wet process is almost as great as that (47 per cent) in plants using the dry process, and in fact the highest percentage volatilizations, 95.9 per cent and 90.7 per cent, were found for plants using the wet process. This result is contrary to what seems to have been the general opinion . among cement manufacturers, as indicated by the following excerpts from communications received from two firms using the wet process: (a) "Our plant is a wet-process plant, and the amount of potash which goes up in the air we figure is infinitesimal as compared with plants using the dry process of manufacture." (b) "In our manufacture of Portland cement we use the wet method of grinding our raw materials and in a short time I believe the entire cement industry will depart from the present dry method and adopt the wet method so that there will be no more precipitation of volatilized potash in our smokestacks."

That a smaller proportion of dust should be carried over mechanically in the wet-process plants is to be expected, and the loss of dust should be particularly reduced in those plants in which the kilns are provided with cross-partition plates which continuously raise the wet slurry and allow it to fall again as a spray. Judging from the observations that have been made in other industries, however, it is not so apparent that the wet process should retard very greatly the escape from the kilns of that portion of the potash which actually is volatilized. 
Thus, R. J. Wysor ${ }^{1}$ has shown in an investigation on the escape of potash from blast furnaces that the specially designed tower spray washers used for purifying the gas from the blast furnace are only moderately efficient in freeing the gas from the finest dust particles, and that much of the water-soluble alkalies remains in the gas current after leaving the washers. This result is explained on the ground that the particles of fume are in such an exceedingly fine state of division that they escape contact with the relatively large drops of water.

Experiments to show the effect of variations in burning on the volatilization of potash have been made recently at the plant of the Security Cement and Lime Co. It was found that as the burning conditions were varied from normal to such a temperature as to give overburned clinker, the percentage volatilization of the potash increased from 31.6 per cent to 42.6 per cent. ${ }^{2}$

A similar result was obtained also in this laboratory in the analysis of seven cement samples furnished us by the Tidewater Portland Cement Co. The samples were collected successively as the burning was raised from a temperature giving a very soft clinker to that sufficient to make a very hard clinker. Corresponding samples of raw mix were collected at the same time, giving a composite sample which analyzed 0.71 per cent potash. The results obtained in the analysis of the cement samples are shown in Table III.

TABLE III.-Effect of variable burning on the liberation of potash in cement kilns.

\begin{tabular}{|c|c|c|c|c|c|}
\hline Sample. & $\begin{array}{l}\text { Potash in } \\
\text { clinker. }\end{array}$ & $\begin{array}{l}\text { Proportion } \\
\text { of total } \\
\text { potash } \\
\text { volatilized. }\end{array}$ & Sample. & $\begin{array}{l}\text { Potash in } \\
\text { clinker. }\end{array}$ & $\begin{array}{l}\text { Proportion } \\
\text { of total } \\
\text { potash } \\
\text { volatilized. }\end{array}$ \\
\hline $\begin{array}{l}\text { No. } 1 \text { a } \\
\text { No. } 2 \ldots \ldots \ldots \ldots \\
\text { No. } 3 \ldots \ldots \ldots \\
\text { No. } 4 \ldots \ldots \ldots \ldots \\
\end{array}$ & $\begin{array}{c}\text { Per cent. } \\
0.69 \\
.70 \\
.58 \\
.54\end{array}$ & $\begin{array}{l}\text { Per cent. } \\
40.0 \\
39.1 \\
49.5 \\
50.7\end{array}$ & $\begin{array}{l}\text { No. } 5 \ldots \ldots \ldots \\
\text { No. } 6 \ldots \ldots \ldots \\
\text { No } 7 b_{\ldots} \ldots\end{array}$ & $\begin{array}{l}\text { Per cent. } \\
0.51 \\
.44 \\
.48\end{array}$ & $\begin{array}{l}\text { Per cent. } \\
55.6 \\
\quad 61.7 \\
58.4\end{array}$ \\
\hline
\end{tabular}

$a$ Very soft.

$b$ Very hard.

These results show that the potash rolatilized increases with the temperature of burning, but the increase apparently is not sufficient to attribute the great variation in the potash volatilized in different plants entirely to differences in the temperature of burning.

That it is possible also to bring about by chemical means an increase in the amount of potash rolatilized has been demonstrated recently at the plant of the Security Cement and Lime Co. This is effected by adding ordinary salt both to the raw mix and to the coal used for fuel, and in such quantity that the total added amounts 
to 1 per cent of the raw mix. The salt is added in the solid state and is brought into intimate mixture with the raw mix and coal by being ground with these materials. The quality of the resulting cement is in no sense impaired by the addition of the salt, for it is found that the total alkalies in the clinker when salt is added to the charge are actually less than when no salt is added, due to the fact that the percentage of the potash is reduced more than the percentage of the soda is increased. By this treatment the percentage of the potash volatilized, which at this plant normally runs about 38 per cent, is increased to about 65 per cent. Assuming that this percentage volatilization ( 65 per cent) could be attained by chemical or other means in all plants where a lower volatilization normally prevails, then it may be estimated that the recoverable available potash in the cement plants of this country would be increased from 71,000 tons to 101,000 tons annually. In making this calculation it is assumed as before that 90 per cent of the total potash volatilized is recovered, but that the additional recoverable potash is all availaole.

Other processes that have been proposed for bringing about an increase in the volatilization of the potash involve treatment with such reagents as calcium chloride,${ }^{1}$ calcium fluoride, ${ }^{2}$ sulphur dioxide,${ }^{3}$ and steam. ${ }^{3}$

The method of increasing the volatilization of the potash by use of calcium fluoride as proposed by Huber and Reath ${ }^{4}$ has been tested on a commercial scale and is worthy of special mention. In this process the fluorine compound is first added to the argillaceous component of the cement material in the form of fluorite and in quantity approximately equivalent to the potassium present. This material is then properly proportioned with limestone to give normal Portlandcement raw mixture and burned in a rotary kiln in the usual way. Volatilization of the potash under these conditions largely takes place in the form of the fluoride, which, as it escapes from the kilns, becomes associated with the salts of calcium carried over mechanically in the dust. It thus happens that when the dust is leached with hot water the potash passes into solution as sulphate or carbonate, while the fluorine remains behind as insoluble calcium fluoride. On using the residue as cement material the same fluorine is fed into the furnace again and may thus be repeatedly used in bringing about increased volatilization of the potash.

${ }^{1}$ Herstein, B., J. Ind. Eng. Chem., 3, 426 (1911); Ross, William H., Circ. No. 71, Bureau of Soils; Brown, H. E., U. S. Patents Nos. 1,123,841 and 1,124,238; Ellis, C., U. S. Patent No. 1,186,522; Spackman, H. S., and Conwell, E. L., U. S. Patent No. 1,202,327.

2 Ellis, C., U. S. Patent No. 1,186,522; Huber, A. W., and Reath, F. F., U. S. Patents Nos. 1,194,344 and 1,219,315; Spackman, H. S., and Conwell, E. L., U. S. Patent No. 1,202,327.

${ }^{3}$ Spackman, H. S., and Conwell, E. L., U. S. Patent No. 1,202,327.

${ }_{4}^{4}$ Loc. cit. 


\section{RELIABILITY OF THE RESULTS OBTAINED.}

All potash determinations were made by the J. Lawrence Smith method, modified by converting the chlorides into sulphates to insure against loss of potash on driving off ammonium salts and then proceeding as in determining water-soluble potash according to the Methods of the Association of Official Agricultural Chemists. The duplicate determinations in every case were made by different persons and each percentage value for potash in raw mix and in cement thus represents the mean of the results found by two analysts. No percentage values of which a mean was taken differed by more than 0.12 , and most differences in results were well within this limit.

When requesting samples for analysis from the different plants attention was called to the importance of selecting cement and rawmix samples which correspond as closely as possible with one another, and which were representative of normal working conditions. This request seems to have been observed by most if not all plants, and judging by letters received it appears that a great deal of care was taken by many cement officials in collecting the samples. Each sample selected for analysis was reduced to a fineness of 175 mesh by grinding the portion which failed to pass through the screen, first in a steel-ball mill and then by hand in an agate mortar. The mills were not asked to make a distinction between the ground clinker and finished cement, for the extent to which these would differ in composition in any particular case through the addition of gypsum to the former was not thought sufficient to have any material effect on the results.

Analyses corresponding to those given in Table I have been made by the Western Precipitation Co. ${ }^{1}$ of samples from five of the plants listed in the table. The results obtained are compared with those found in this laboratory in Table IV:

TABLE IV.-Comparison of results of analyses made by the Westorn Precipitation Co., and by the Bureau of Soils of raw-mix and cement samples collected on different occasions.

\begin{tabular}{|c|c|c|c|c|}
\hline \multirow[b]{2}{*}{ Company. } & \multicolumn{2}{|c|}{ Potash in raw mix. } & \multicolumn{2}{|c|}{ Potash in cement. } \\
\hline & $\begin{array}{l}\text { Bureau } \\
\text { of Soils. }\end{array}$ & $\begin{array}{l}\text { Western } \\
\text { Precipita- } \\
\text { tion Co. }\end{array}$ & $\begin{array}{l}\text { Bureau } \\
\text { of Soils. }\end{array}$ & $\begin{array}{l}\text { Western } \\
\text { Precipita- } \\
\text { tion Co. }\end{array}$ \\
\hline 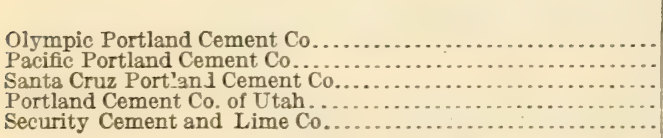 & $\begin{array}{r}\text { Per cent. } \\
0.56 \\
.50 \\
.76 \\
.94 \\
1.29\end{array}$ & \begin{tabular}{|r|} 
Per cent. \\
0.42 \\
.52 \\
.76 \\
.92 \\
1.12
\end{tabular} & $\begin{array}{r}\text { Per cent. } \\
0.51 \\
.50 \\
.33 \\
.24 \\
1.05\end{array}$ & $\begin{array}{r}\text { Per cent. } \\
0.45 \\
.43 \\
.28 \\
.21 \\
1.02\end{array}$ \\
\hline
\end{tabular}

1 Written communication. 
The two sets of analyses shown in this table were made on different samples collected from four months to six months apart. The close agreement in each case affords evidence that at least for these plants the samples collected are representative, and that the potash content of the raw material used in cement manufacture is surprisingly uniform.

Further evidence in support of this conclusion is available. Thus, R. K. Meade, consulting engineer for the Clinchfield Portland Cement Co., reports ${ }^{1}$ that he found 2.49 pounds of potash volatilized at this plant per barrel of cement, basing his calculations on the results of analyses of samples secured about a year prior to the time that our samples were obtained. This result differs but 0.03 pound from that given in Table I. Again, of two samples of raw mix which were collected and forwarded to this laboratory nine months apart by the Tidewater Portland Cement Co., both were found to contain 0.71 per cent potash.

It may be pointed out also that as a rule those plants which are situated near one another and apparently use material from the same geological formation show much the same potash content in the raw material used. Thus, there may be compared in this connection the different plants at Bath, Pa.; Nazareth, Pa.; Fenton, Mich.; Mason City, Iowa; Concrete, Wash.; and Hudson, N. Y.

The values listed in Table I for the weights of dry raw mix required per barrel of cement show greater variation than might be expected, and it is possible that some of the values given may depart somewhat from values representing true working conditions. Where no values could be obtained it was assumed that 608 pounds of raw mix would be required per barrel of cement. It is recognized, also, that in individual cases the samples collected may not be representative of normal working conditions, but from the observations made it is thought that in the majority of cases the results given are representative.

\section{ESTIMATED PERCENTAGE OF POTASH IN THE FLUE DUST FROM DIFFERENT PLANTS.}

The percentage of potash occurring in the flue dust from any plant will vary (1) with the percentage of potash in the raw material; (2) with the percentage of potash volatilized; and (3) with the amount of dust carried off from the kilns mechanically.

As already pointed out, the quantity of dust collected daily in the flue stacks and truaters of the plant of the Security Cement and Lime Co. amounts to about 61,000 pounds. . If it be assumed that this represents a recovery of 95 per cent of the total dust, 
then the total dust escaping from the kilns of this plant amounts to about 4 per cent of the charge fed into the kilns. If it be assumed that the dust thus collected has undergone about 50 per cent calcination, then the true loss of raw mix in the form of dust will amount to 5 per cent, which is recognized to be a fair average for the plants of this country using the dry process. In calculating the values given in the last column of Table I, the dust lost from the kilns in plants using this process was accordingly taken as 4 per cent.

On this basis of a 4 per cent loss as dust, the potash contained in the dust from the Security plant should amount to 10.9 per cent. It happens, however, that 27 per cent of the dust, containing about 4.5 per cent of potash, is collected in the flue stacks which connect the kilns with the treaters, and, therefore, the remaining dust, assuming a 90 per cent precipitation of the potash, should contain 11.1 per cent of potash. A sample of this dust analyzed in this laboratory was found to contain 11.4 per cent of potash.

The quantity of dust lost from plants using the wet process is dependent on a number of factors, such as the dimensions of the kiln, the amount of water in the slurry, and the plasticity of the raw mix. Estimates which have been given the writers vary between rather wide limits. On the basis of the most reliable information obtained, it is probable that a loss as dust amounting to 2 per cent of the raw mix is a fair average. This value was therefore used in estimating the percentage of potash in the dust from wet-process plants. The actual potash content of the dust escaping from any plant will be greater or less than the values given according as the true percentage of dust lost is less or greater than the value cited.

As shown in experiments which are to be described in detail in a subsequent publication, the usual constituents of the water extract of freshly collected flue dust are sulphates, chlorides, sulphides, and polysulphides of potash, soda, and lime. Chlorides occur only in small amounts. The percentage of sulphides and polysulphides in the dust from different plants may vary greatly, and in some cases they may be entirely absent. Free lime is found in all cement dust, and in the water extract of all samples analyzed the basic radicals were found to be in excess. It follows, therefore, that the potash in the water extract of freshly collected flue dust will be present to a greater or less extent in the form of the hydroxide. As the dust becomes carbonated either by chemical treatment or by exposure to the air, the hydroxides present will change into carbonates, and the water-soluble potash then will be obtained principally in the form of the sulphate, which is the form universally recognized as of most value for use as a fertilizer.

The flue dust as collected by electrical precipitation may be (1) used directly as a source of cement material; (2) disposed of as collected for use as a fertilizer or in fertilizer manufacture; or (3) leached 
with a view to preparing concentrated potash salts. The value of the dust as a source of cement material is estimated usually at about 75 cents per ton. The value of potash in the form of sulphate depends on the concentration and varies at normal wholesale prices from about 70 cents per unit for low-grade material to about 90 cents per unit in material containing a minimum of 48 per cent potassium sulphate, or to 95 cents in material containing a minimum of 90 per cent potassium sulphate. Thus it is seen that a comparatively low. percentage of potash in flue dust is sufficient to give it more value as a source of potash than as cement material. By separating and concentrating the potash occurring in flue dust the price thereof per unit is increased, the cost of transportation is reduced, the residue becomes available for cement manufacture, and if the process of separation involves some such treatment as steaming under pressure, the percentage of available potash in the dust of some plants at least may be increased considerably. Against these advantages incident to the separation of the dust must be balanced the relative cost of the operation, which will be dependent on the percentage of potash in the dust. The best method of disposing of the dust is thus dependent on a number of factors which will vary with conditions, and it thus happens that all of the three procedures referred to for utilizing the dust are now being given practical application in plants where the dust is being collected by electrical precipitation.

The work so far done on the recovery of potash from cement plants apparently has been limited to plants using the dry process. No installation for the electrical recovery of the dust has yet been made in plants using the wet process, but it is probable that the electrical method would prove just as applicable to plants of this kind as to those using the dry process. At the temperature at which the gases leave the kilns no precipitation of water would take place, and as long as the temperature of the gases is maintained above $100^{\circ}$ while passing through the treater pipes little condensation of moisture should occur. The dust in all probability would be precipitated either in a dry state or as a mud or slurry. If precipitated in the form of a slurry, no electrode hammering system would then be necessary, for the precipitated material would flow down the pipes continuously and a concentrated solution of salts would thus be obtained directly without the necessity of any special treatment.

\section{RATIO OF POTASH TO SODA IN CEMENT DUST.}

The extent to which the potash salts in flue dust may be concentrated conveniently is dependent in a large measure on the proportion of sodium salts also present in the dust. It was, therefore, thought advisable to determine the proportion to be expected for a number of plants with a view to gaining some idea as to the quantity of soda that might be contained in the dust. The results are given in Table V. 
TABLE V.-Comparison of the amounts of potash and soda lost in cement manufacture.

\begin{tabular}{|c|c|c|c|c|c|c|c|c|c|c|c|}
\hline \multirow{2}{*}{ Company. } & \multirow{2}{*}{ Plant. } & \multicolumn{2}{|c|}{ Raw mix. } & \multicolumn{2}{|c|}{ Cement. } & \multicolumn{2}{|c|}{$\begin{array}{l}\text { Loss from } \\
\text { kilns. }\end{array}$} & \multirow{2}{*}{$\begin{array}{l}\text { Ra- } \\
\text { tio of } \\
\text { per- } \\
\text { cent- } \\
\text { age } \\
\text { losses. }\end{array}$} & \multicolumn{2}{|c|}{$\begin{array}{l}\text { Loss per } \\
\text { barrel of } \\
\text { cement. }\end{array}$} & \multirow{2}{*}{$\begin{array}{l}\text { Ra- } \\
\text { tio of } \\
\text { pot- } \\
\text { ash to } \\
\text { soda } \\
\text { in liue } \\
\text { dust. }\end{array}$} \\
\hline & & $\begin{array}{l}\text { Pot- } \\
\text { ash. }\end{array}$ & Soda. & $\begin{array}{l}\text { Pot- } \\
\text { ash. }\end{array}$ & Soda. & $\begin{array}{l}\text { Pot- } \\
\text { ash. }\end{array}$ & Soda & & $\begin{array}{l}\text { Pot- } \\
\text { ash. }\end{array}$ & Soda. & \\
\hline Alpha Portland Cement & Martin's Creek & P. ct. & $\begin{array}{l}\text { P. ct. } \\
0.48\end{array}$ & $\begin{array}{l}P . c t \text {. } \\
0.77\end{array}$ & P. ct. & $\begin{array}{l}\text { P. ct. } \\
49.1\end{array}$ & $\begin{array}{l}\text { P.ct. } \\
36.7\end{array}$ & 1.34 & $\begin{array}{l}L b s . \\
2.82\end{array}$ & $\begin{array}{l}\text { Lbs. } \\
1.10\end{array}$ & 2.56 \\
\hline $\begin{array}{l}\text { Co. } \\
\text { ment Co. }\end{array}$ & & .77 & .39 & .63 & .48 & 50.6 & 25.8 & 1.96 & 2.46 & .63 & 3.90 \\
\hline $\begin{array}{l}\text { Cowell Portland } \mathrm{Ce}- \\
\text { ment Co. }\end{array}$ & & .59 & .43 & .55 & .49 & 41.7 & 28.8 & 1.45 & 1.50 & .75 & 2.00 \\
\hline $\begin{array}{l}\text { Edison Portland } \mathrm{Ce}- \\
\text { ment } \mathrm{Co} \text {. }\end{array}$ & & .69 & .59 & .70 & .49 & 39.8 & 50.7 & .78 & 1.76 & 1.91 & .92 \\
\hline $\begin{array}{l}\text { Giant Portland Cement } \\
\text { Co. }\end{array}$ & Egypt & .77 & .52 & .59 & .57 & 54.5 & 34.9 & 1.56 & 2.69 & 1.16 & 2.32 \\
\hline $\begin{array}{l}\text { Iola Portland Cement } \\
\text { Co. }\end{array}$ & & .58 & .54 & .60 & .61 & 39.2 & 33.6 & 1.17 & 1.47 & 1.17 & 1.26 \\
\hline $\begin{array}{l}\text { Knickerbocker Portland } \\
\text { Cement Co. }\end{array}$ & & .81 & .50 & .78 & .59 & 38.3 & 24.4 & 1.57 & 1.84 & .72 & 2.56 \\
\hline $\begin{array}{l}\text { Lawrence Portland Ce- } \\
\text { ment Co. }\end{array}$ & & 1.01 & .53 & .88 & .55 & 45.7 & 35.4 & 1.29 & 2.82 & 1.14 & 2.47 \\
\hline $\begin{array}{l}\text { Lehigh Portland Ce- } \\
\text { ment Co. }\end{array}$ & Fogelsville. & .71 & .45 & .47 & .38 & 58.6 & 47.2 & 1.24 & 2.53 & 1.29 & 1.96 \\
\hline $\begin{array}{l}\text { Do } \ldots \ldots \ldots \ldots \ldots \\
\text { Do................... }\end{array}$ & & $\begin{array}{l}.79 \\
63\end{array}$ & $\begin{array}{l}.61 \\
.39\end{array}$ & $\begin{array}{l}.71 \\
.38\end{array}$ & $\begin{array}{l}.71 \\
.52\end{array}$ & $\begin{array}{l}43.8 \\
62.2\end{array}$ & $\begin{array}{l}27.2 \\
16.4\end{array}$ & $\begin{array}{l}1.61 \\
3.80\end{array}$ & $\begin{array}{l}2.11 \\
2.37\end{array}$ & $\begin{array}{r}1.01 \\
.39\end{array}$ & 2.0 \\
\hline Do. & Mason City. & 1.00 & .50 & .63 & .61 & 61.5 & 25.5 & 2.41 & 3.82 & .79 & $\begin{array}{l}0.07 \\
4.84\end{array}$ \\
\hline $\begin{array}{l}\text { Marquette Portland Ce- } \\
\text { ment Co. }\end{array}$ & & .70 & .58 & .63 & .66 & 44.4 & 29.7 & 1.49 & 1.91 & 1.06 & 1.80 \\
\hline $\begin{array}{l}\text { Nazareth Cement Co... } \\
\text { Northwestern States } \\
\text { Portland Cement Co. }\end{array}$ & & $\begin{array}{r}.84 \\
1.08\end{array}$ & $\begin{array}{l}.61 \\
.43\end{array}$ & $\begin{array}{l}.64 \\
.99\end{array}$ & $\begin{array}{l}.60 \\
.44\end{array}$ & $\begin{array}{l}53.3 \\
41.9\end{array}$ & $\begin{array}{l}39.7 \\
38.3\end{array}$ & $\begin{array}{l}1.34 \\
1.09\end{array}$ & $\begin{array}{l}2.78 \\
2.72\end{array}$ & $\begin{array}{l}1.50 \\
1.04\end{array}$ & $\begin{array}{l}1.85 \\
2.62\end{array}$ \\
\hline $\begin{array}{l}\text { Pacific Portland Cement } \\
\text { Co. }\end{array}$ & & .50 & .71 & .50 & .98 & 35.0 & 10.3 & 3.40 & 1.03 & .43 & $2.4 \theta$ \\
\hline $\begin{array}{l}\text { Portland Cement Co. } \\
\text { of Utah. }\end{array}$ & & .94 & .70 & .24 & .95 & 84.9 & 45.2 & 1.88 & 5.14 & 2.04 & 2.52 \\
\hline $\begin{array}{l}\text { Texas Portland Cement } \\
\text { Co. }\end{array}$ & & .90 & .37 & .81 & .45 & 43.9 & 24.2 & 1.81 & 2.41 & .55 & 4.38 \\
\hline $\begin{array}{l}\text { Vulcanite Portland Ce- } \\
\text { ment Co. }\end{array}$ & & .58 & .36 & .58 & .41 & 40.6 & 32.4 & 1.25 & 1.51 & .75 & 2.00 \\
\hline $\begin{array}{l}\text { Whitehall Portland Ce- } \\
\text { ment Co. }\end{array}$ & & .77 & .58 & .58 & .66 & 50.6 & 25.4 & 1.99 & 2.26 & .85 & 2.66 \\
\hline
\end{tabular}

Table $\mathrm{V}$ shows that for those cases examined the percentage of potash in the raw mix with one exception is in excess of the percentage of soda. With one exception, also, the percentages of potash volatilized are considerably in excess of the corresponding values found for soda. It consequently happens that the calculated excess of potash over soda in the dust is in most cases quite marked, the ratio of potash to soda varying in the case of the samples examined from 0.92 to 6.07 , with an average of 2.66 .

\section{POTASH-PRODUCING PLANTS IN THE UNITED STATES.}

The recovery of the potash which escapes from the stacks of cement kilns was first made at the plant of the Riverside Portland Cement Co., using the Cottrell process of electrical precipitation. The first unit of this installation was completed in 1912, and has been in continuous operation ever since. The following year the installation was enlarged to take care of the gases from 10 kilns, which comprised all the kilns in the plant at that time. This main installation is built on the plate and wire principle, ${ }^{1}$ wherein flat 
plates take the place of the pipes used in later installations as collecting electrodes and the gases flow horizontally between the plates instead of vertically as is the case where pipes are used. Two kilns were later added to the equipment of the original plant, and to take care of the gases from these kilns the multiple-pipe system was installed.

In the case of the plate and wire treater a separation of the dust according to the size of the particles is in a measure effected during the process of precipitation, and it thus happens that the fineness of the dust collected and the percentage of potash present in the precipitated dust increase with the distance of the collecting hoppers from the kilns. In the multiple-pipe treater, however, no separation of the dust takes place other than that brought about by deposition of dust in the flues connecting the treater with the kilns. This dust is coarser and contains a lower percentage of potash than the average of that precipitated.

In the original method used for taking care of the material precipitated at this plant all of the collected dust was burned in one of the kilns connected with the multiple-pipe treater, and the dust there precipitated separately collected. The dust thus recovered on second precipitation showed a marked concentration of potash, which sometimes ran as high as 20 to 23 per cent. This process of concentrating the potash was abandoned later, as it was found that the potassium sulphate in the treater dust was less readily volatilized than the potash in the original mix, and although a high-grade potash material could be obtained in this way the double treatment actually resulted in a loss of potash, due to the comparatively greater percentage contained in the final clinker.

In the method now followed for disposing of the collected material the coarse dust which settles in the long connecting flue of the multiplepipe treater and in the two rows of hoppers nearest the kilns in the plate and wire treater is returned to the kilns for use as cement material. The dust precipitated in the multiple-pipe treater and in the two remaining rows of the plate and wire treater is separately collected and is either disposed of directly for use as a fertilizer or leached with water at a temperature above $85^{\circ}$ for the preparation of concentrated potash salts. ${ }^{1}$ By the use of feldspar the potash in the raw mix at this plant has recently been increased considerably above the value given in Table I, with corresponding gains in the quantity of potash volatilized and recovered.

In the plant of the Security Cement and Lime Co. the multiplepipe system alone is used. In this installation the original flue stacks are still retained, and each serves as part of the connecting flue which conducts the gases from the corresponding kiln or kilns to the treater with which it is connected. By this indirect method of connecting the kilns with the precipitating system the gases before

1 Huber, F. W., and Reath, F. F., U. S. Patent No. 1,220,989. 
entering the treaters are cooled by radiation in the flues to the desired temperature for the precipitation of the dust.

Several precipitating installations are also in operation at plants controlled by the Universal Portland Cement Co., but as indicated in Table I the dust from these plants is too low grade to be of value as a source of potash. The dust collected in the treaters at these plants, therefore, is returned to the kilns automatically, for use as cement material.

In the precipitating system recently installed at the Cementon plant of the Alpha Portland Cement Co., the gases from the kilns are passed successively through a boiler and economizer system before entering the treaters. In this way the waste heat of the gases is utilized for the generation of power by steam turbines. In this installation, as well as in the multiple-pipe treaters already referred to, an artificial draft produced by a fan placed beyond the treater system replaces the natural draft originally given by the flue stacks.

The advantages claimed for installations of the kind last mentioned are as follows: (1) The abatement of the dust nuisance is effectively secured; (2) material is recovered suitable as a source of potash or cement material or of both when separation of the potash is brought about; (3) a greater efficiency in the burning of the cement is secured owing to better possible regulation of the draft through the kilns, with resultant economy in the amount of fuel required; and (4) utilization of the waste heat of the gases from the kilns.

In the plant of the California Portland Cement Co. use is made of the Fleming patent dust-collecting system. ${ }^{1}$ This system has been in operation since 1912, and it is claimed that this method of collecting the dust is not only efficient but it is also more than self-supporting, there being a saving to the companv in the dust collected, a larger output per barrel of oil used for fuel, and fewer shutdowns than before the Fleming system was installed.

The draft for the kilns is produced by fans sucking at the end of separate flues. Instead of discharging the gases into the atmosphere, these fans blow the dust and fumes into a large dry dust-settling chamber, where the velocity of the gases is reduced 90 to 95 per cent and about two-thirds of the dust is deposited. The gases carrying the extremely fine dust which does not settle then go to wet washing chambers, where they are forced up and down several times through a system of seven baffle sections in each of which are sprays of water for capturing the remaining dust. In both the wet and dry chambers means are provided for remoring the collected dust to the cement kilns. The same water being repeatedly used in the wet baffle chambers, it soon becomes charged with soluble salts, principally in the form of sulphur compounds of potassium, sodium, and calcium. When more than one-half pound per cubic foot is found some of the solution is removed. and replaced by fresh water in order not to cause trouble

1 Hanna, W. C., Metallurgical and Chemical Engineering 13, 609 (1915). 
with the sprays. Steps are now taken to recover the potash, but further details of the operation are held confidential.

Extensive experiments on a wet process for the recovery of potash in cement dust have also been made at the plant of the Sandusky Cement Co. One method of procedure as outlined in a patent $t^{1}$ granted to the president of this company has for its object the recovery of the water-soluble potash in the dust. This is done (1) by causing the gases to pass over water contained in shallow vessels in which the solution of alkali salt is produced and replaced as it becomes saturated, or (2) by causing the gases to pass upward through a tower filled with an open checkerwork of brick at the top of which a spray of water is introduced. The flue is so adjusted that most of the water is evaporated in its descent over the extensive brickwork surface in contact with the gases and a small stream only of a concentrated salt solution is discharged continually at the bottom of the tower.

In a process described in the specifications of a subsequent patent ${ }^{2}$ provision is also made for the recovery of the insoluble potash in the dust and for utilizing the waste heat of the gases. This is done by passing the gases first through suitable dust chambers and then successively through a boiler and economizer system before passing into the spray system as outlined in the preceding patent. The dust which is deposited in the connecting flues of the system and the mud which settles out from the concentrated salt solutions are then returned to the kilns for the purpose of volatilizing the potash present with a view to its ultimate recovery in soluble form. The experiments on the commercial application of the methods outlined in these patents have not yet been completed. It seems doubtful, however, from observations made in various industries on the use of spray washers for the purification of gases from a suspended fume, whether any wet process will prove as effective as the electrical process for the recovery of potash from cement flue dust.

The recovery of potash from feldspar by use of the latter in the manufacture of cement has recently been investigated or a commercial scale by the Buffalo Potash \& Cement Corporation, operating under the Brown ${ }^{3}$ and Warren ${ }^{4}$ patents.

In the process outlined in these patents feldspar is ignited in an oxidizing atmosphere with a sufficient quantity of calcium chloride to furnish sufficient chlorine to combine with the potassium in the feldspar and with a sufficient quantity of calcium carbonate to bring the lime content of the resulting material up to 40 to 55 per cent. The charge is burned in a modified type of copper blast furnace at a temperature practically the same as that required in Portland-cement practice with rotary kilns. Under the conditions of the operation the charge is reduced to a molten mass yielding a cement containing no

1 Newberry, S. B., U. S. Patent No. 1,121,532.

2 Newberry, S. B., U. S. Patent No. 1,150,295.
3 U. S. Patents Nos. 1,123,841 and 1,124,238.

U. S. Patent No. 1,123,964. 
free lime and at the same time a high percentage volatilization of the potash is obtained. A combined dry and wet system was first used for recovering the potash, but, not proving satisfactory, this has been replaced by the Cottrell process of electrical precipitation.

\section{ACKNOWLEDGMENT.}

We wish to express our thanks to the different cement companies listed in Table I for the samples they have furnished us, and particularly to the officials of the Security Cement and Lime Co., the Western Precipitation Co., Mr. R. K. Meade, and others, for the information they have given us.

\section{SUMMARY.}

(1) Analysis of samples of raw mix and of cement from 113 cement mills in the United States and Canada shows that the potash in the raw mix varies from 0.20 to 1.16 per cent, and that the percentage of potash volatilized in the different plants varies from 24.5 to 95.9 per cent. From the results thus obtained it has been calculated that the potash escaping from the kilns of these plants ranges from 0.35 to 5.14 pounds per barrel of cement produced, with an average for the plants of this country of 1.93 pounds. On the basis of an average production of $90,000,000$ barrels, the total potash escaping from the cement plants of this country amounts to about 87,000 tons annually. It has been demonstrated commercially that 90 per cent of the potash escaping in the dust is recoverable, and from experiments made in this laboratory it would appear that 95 per cent of the recoverable potash is, or may readily be made, available. The recoverable potash in the cement industry therefore amounts to approximately 78,000 tons and the available recoverable potash to 75,000 tons, or to 71,000 tons when plants losing less than 1 pound of potash per barrel of cement are omitted.

(2) Assuming, in the light of results that have already been obtained, that it would be practicable to increase the percentage of potash volatilized to at least 65 per cent for all plants, then the available recoverable potash would amount to more than 100,000 tons annually, or to nearly one-half of the normal consumption of potash in this country.

(3) If it be assumed, further, that the dust escaping from the kilns amounts on an average to 4 per cent of the raw mix fed into the kilns in the case of dry-process plants, and to 2 per cent for plants using the wet process, then, on the basis of the results already given, the total potash content of the dust escaping from the former plants will vary in different plants from 1.4 to 20.0 per cent, and in the latter from 9.1 to 35.1 per cent.

(4) The ratio of potash to soda in the dust as determined for 20 different plants varies from 0.92 to 6.07 , with an average of 2.66 . 


\section{PUBLICATIONS OF THE UNITED STATES DEPARTMENT OF AGRICUL- TURE RELATING TO THE PRODUCTION OF POTASH.}

\section{AVAILABLE FOR FREE DISTRIBUTION BY THE DEPARTMENT.}

The Topographic Features of the Desert Basin of the United States with Reference to the Possible Occurrence of Potash. Department Bulletin No. 54.

Potash Salts and other Salines in the Great Basin Region. Department Bulletin No. 61.

Investigation of the Otero Basin, New Mexico, for Potash Salts. Soils Circular No. 61. Alunite as a Source of Potash. Soils Circular No. 70.

The Extraction of Potash from Silicate Rocks. Soils Circular No. 71.

Potash from Kelp. Secretary's Report 100.

FOR SALE BY THE SUPERINTENDENT OF DOCUMENTS, GOVERNMENT PRINTING OFFICE, WASHINGTON, D. C.

The Production and Fertilizer Value of Citric Soluble Phosphoric Acid and Potash.

Department Bulletin No. 143. Price, 5 cents.

The Recovery of Potash from Alunite. Department Bulletin No. 415. Price, 5 cents. Possible Sources of Potash in the United States. Year Book, 1912, Separate 611. Price, 5 cents.

Importance of Developing our Natural Resources of Potash. Year Book, 1916, Separate 717. Price, 5 cents.

The Occurrence of Potassium Salts in the Salines of the United States. Soils Bulletin No. 94. Price, 15 cents.

Alunite and Kelp as Potash Fertilizers. Soils Circular 76. Price, 5 cents.

ADDITIONAL COPIES

OF THIS PUBLICATION MAY BE PROCURED FROM THE SUPERINTENDENT OF DOCUMENTS

GOVERNMENT PRINTING OFFICE WASHINGTON, D. C. AT

5 CENTS PER COPY 




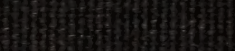

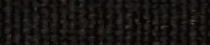

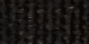

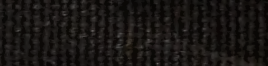

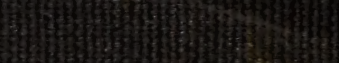

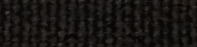

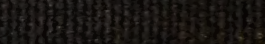

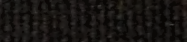

: 